
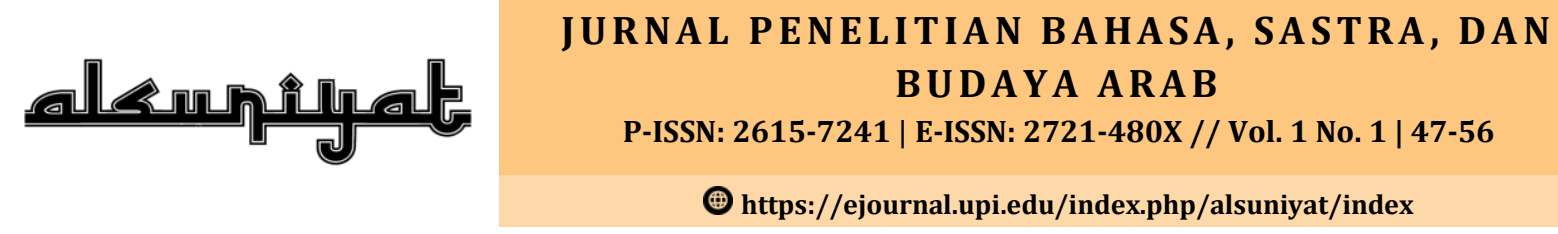

๑) https://ejournal.upi.edu/index.php/alsuniyat/index

\title{
EFEKTIVITAS PENGGUNAAN TEKNIK CLUSTERING TERHADAP PENINGKATAN KETERAMPILAN SISWA DALAM MENULIS KARANGAN DESKRIPSI (INSYA)
}

\author{
Rinaldi Supriadi \\ Universitas Kebangsaan Republik Indonesia Bandung, Indonesia \\ Email: aldeyrinaldi20@gmail.com
}

\begin{abstract}
Abstrct
This research is motivated by the ability of students who are still relatively weak in terms of writing using Arabic. Though their intensity to learn Arabic is more than that of students in public high schools that have Arabic learning in it. One technique that can be used in learning to write descriptive essays or in Arabic is in clustering techniques. In this technique there are several stages for writing a description or in writing, wherein with this technique students get inspiration in their minds to pour into their wills. In this study, researchers used a Quasi-experimental method, with Non-Equivalent Control Group Design. In this study, researchers selected experimental group members and control group members each of 30 people. Furthermore, the experimental group was treated as a clustering technique, while the control group did not receive the same treatment using the lecture method. Thus there is a positive and significant relationship and influence on the ability of God willing to use clustering techniques.
\end{abstract}

Keywords:

Clustering Techniques; Skills; Essay description (Insya)

\begin{abstract}
Abstrak
Penelitian ini dilatar belakangi oleh kemampuan siswa yang masih tergolong rendah dalam hal menulis dengan menggunakan bahasa Arab. Padahal intensitas mereka untuk belajar bahasa Arab lebih banyak dibandingkan dengan siswa di sekolah menengah umum yang terdapat pembelajaran bahasa Arab didalamnya. Salah satu teknik yang bisa digunakan dalam pembelajaran menulis karangan deskripsi atau dalam bahasa Arab insya adalah teknik clustering. Dalam teknik ini terdapat beberapa tahapan untuk menulis karangan deskripsi atau dalam insya, dimana dengan teknik ini siswa mendapatkan inspirasi dalam pikirannya untuk dituangkan dalam tulisan. Dalam penelitian ini peneliti menggunakan metode Kuasi-eksperimen, dengan desain Non-Equivalent Control Group Design. Dalam penelitian ini, peneliti memilih anggota kelompok eksperimen dan anggota kelompok kontrol masing-masing 30 orang. Selanjutnya kelompok eksperimen dikenai perlakuan (treatment) yaitu teknik clustering, sementara kelompok kontrol tidak menerima perlakuan yang sama yaitu dengan menggunakan metode ceramah. Dengan demikian terdapat hubungan dan pengaruh yang positif serta signifikan pada kemampuan insya dengan menggunakan teknik clustering.

Kata Kunci:

Teknik Clustering; Keterampilan; Karangan deskripsi (Insya)
\end{abstract}

\section{PENDAHULUAN}

Kenyataannya dilapangan membuktikan bahwa kegiatan menulis masih kurang sekali dilakukan oleh masyarakat Indonesia. Hal ini didukung oleh hasil penelitian yang menunjukkan bahwa kegiatan menulis merupakan kegiatan yang paling sedikit dilakukan dibandingkan dengan kegiatan menyimak, berbicara, dan membaca. Sebagaimana hasil penelitian Rankin terhadap keterampilan berbahasa, memperlihatkan perbandingan yang cukup signifikan antara keterampilan menyimak 45\%, berbicara 30\%, membaca 16\%, dan menulis 9\% (Cahyani, 
2002:84). Melihat kondisi demikian, nampaknya kegiatan menulis perlu mendapat perhatian khusus agar bangsa Indonesia tidak lagi dikenal sebagai bangsa aliterasi namun sedikit demi sedikit berubah menjadi bangsa yang akrab dengan kegiatan literasi khususnya menulis. diketahui bahwa diantara empat jenis keterampilan berbahasa (membaca, menyimak, berbicara dan menulis) maka menulis lah yang memang di rasa paling sulit. Selaras dengan kondisi tersebut Hikmawati mengungkapkan pendapat Nurgiyantoro, (2001: 296) bahwa:

Para siswa merasa tidak terlalu bersemangat saat tiba pelajaran insya yang salah satu kegiatannya adalah menulis. Banyak alasan yang muncul mulai dari sulit menemukan ide sampai bingung dari mana harus memulai tulisan. Kondisi demikian diperparah dengan kondisi pembelajaran yang kurang variatif sehingga menyebabkan siswa kurang memiliki motivasi, tidak mau berlatih dan malas menulis. Bagi mereka, pembelajaran menulis merupakan salah satu kegiatan yang dianggap paling sukar dan tidak menyenangkan. Salah satu kelemahan pengjar dalam kelas di negara kita terletak pada komponen metode.

Tujuan utama dari penelitian ini adalah sebagai berikut:

1. Untuk mengetahui keterampilan menulis karangan deskripsi siswa sebelum menggunakan teknik clustering pada mata pelajaran insya.

2. Untuk mengetahui keterampilan menulis karangan deskripsi siswa sesudah menggunakan teknik clustering pada mata pelajaran insya.

3. Untuk menemukan ada atau tidak adanya keefektifitasan penggunaan teknik clustering terhadap peningkatan keterampilan menulis karangan deskripsi siswa kelas pada mata pelajaran insya.

Menurut Hernowo (2006:17), menulis adalah melahirkan pikiran dan perasaan lewat tulisan. Agar efektif menulis menuntut si penulis mengungkapkan gagasannya secara tertib dan tertara sehingga gagasannya menjadi makna yang menyadarkan. Menulis merupakan merupakan suatu aktivitas yang dapat mempercepat proses pencernaan dan penyerapan sebuah penegasan. Lebih jelas lagi, ia mengatakan bahwa menulis merupakan aktivitas intelektual praktis yang dapat dilakukan oleh siapa aja dan amat berguna untuk mengukur sudah seberapa tinggi pertumbuhan rohani seseorang.

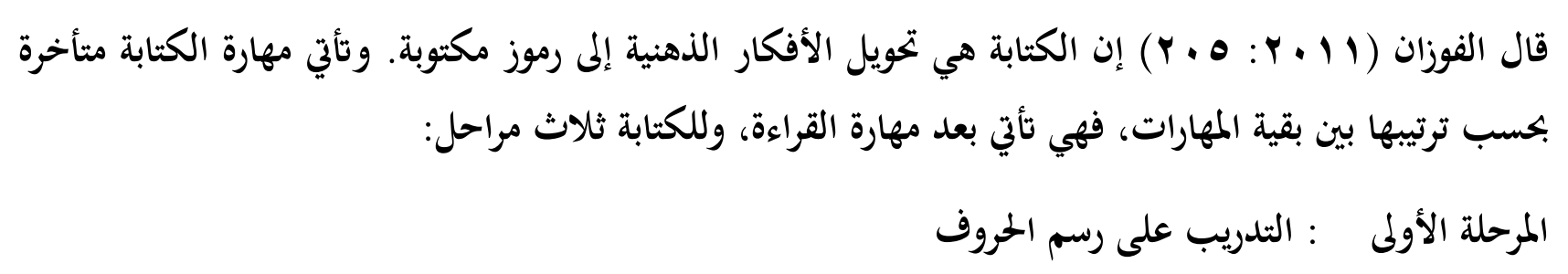




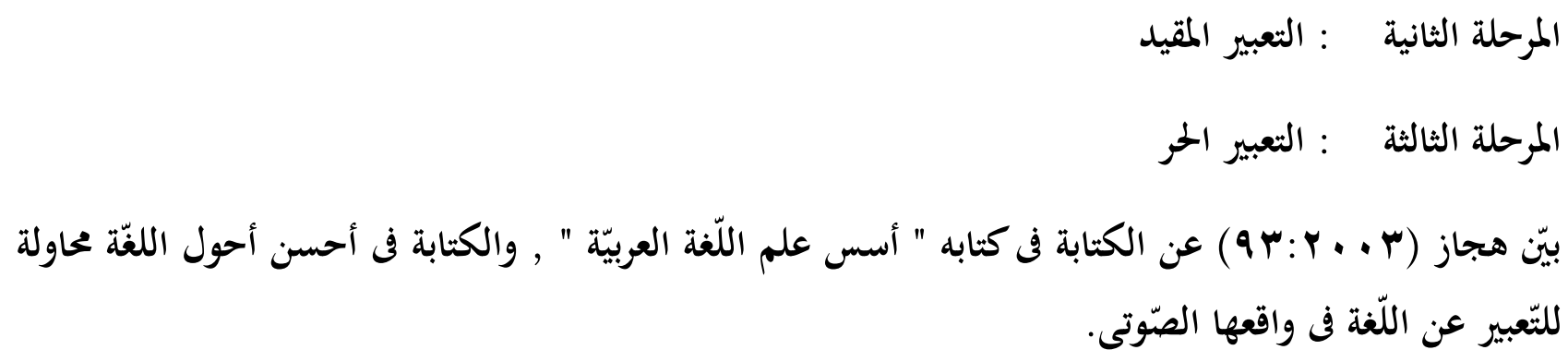

Menurut Nurgiyanto (1995:296) menulis adalah aktivitas produktif, aktivitas pengungkapan bahasa. Secara umum menulis adalah mengungkapkan gagasan melalui media bahasa. Sejalan dengan itu, Tarigan (1994:21) mengungkapkan menulis adalah menirukan atau melukiskan lambang-lambang atau grafikyang menggambarkan suatu bahasa yang dipahami seseorang, shingga orang lain dapat membaca lambang-lambang grafik tersebut jika mereka memahami bahasa dan gambar grafik tersebut.

Kemahiran berbahasa yang harus dikembangkan setelah menyimak, berbicara, dan membaca adalah menulis. Tarigan (2008:22) menjelaskan bahwa menulis ialah menurunkan atau melukiskan lambang lambang grafik yang menggambarkan suatu bahasa yang dipahami oleh seseorang, sehingga orang orang lain dapat membaca lambang grafik tersebut, kalau mereka memahami bahasa dan gambaran grafik itu. Menulis merupakan salah satu representasi bagian dari ekspressi kesatuan kesatuan bahasa.

Kesulitan siswa dalam menulis tidak bisa dihiraukan begitu saja karena menulis memberikan banyak manfaat menurut Alfiyah (2012) "menulis merupakan salah satu cara untuk menambah wawasan. Dengan menulis seseorang akan giat membaca beragam literature guna memperkaya istilah kata dan menambah bahan pembicaraan dalam wujud tulisan".

Al-Khuliy (2002:102) menjelaskan bahwa menulis adalah salahsatu keterampilan berbahasa baik untuk pengajaran bahasa pertama maupun bahasa kedua. Pentahapan pengajaran merupakan prinsip pendidikan yang mesti diaplikasikan dalam berbagai situasi belajar baik untuk materi belajar bahasa maupun untuk materi pelajaran lainnya. Apabila kita terapkan prinsip pentahapan ini dalam pelajaran menulis, kita memulainya dari khat, naskh, (menyalin) imla, atau dikte menulis terstruktur dan kemudian menulis bebas.

Salah satu jenis karangan adalah karangan deskripsi. Menurut Keraf (1982:93) deskripsi atau pemerian adalah sebuah bentuk tulisan yang bertalian dengan usaha para penulis untuk membeberkan perincian-perincian dari objek yang sedang dibicaraka. Kata deskripsi berasal dari latin describere yang berarti menulis tentang atau membeberkan suatu hal. Sedangkan menurut Rahardi (2009:166) paragraph jenis ini disebut juga paragraph lukisan, yakni 
ALSUNIYAT: Jurnal Penelitian Bahasa, Sastra, dan Budaya Arab

melukiskan atau menggambarkan apa saja yang dilihat di depan mata penulisnya. Jadi, paragraph deskriptif ini bersifat loyal terhadap tata ruang atau tata letak objek yang dituliskan itu.

Teknik clustering adalah suatu teknik yang memilah pemikiran-pemikiran yang saling berkaitan dan menuangkannya diatas kertas secepatya, tanpa mempertimbangkan kebenaran atau nilainya (DePotter dan Hernacki, 2000:181).

Dawson and Essid in (www.writing2.richmond.edu/writing/wweb/cluster. html-4k), say that clustering is a type of prewriting that allows the learners to explore many ideas as soon as they occur to the learners. Like brainstorming or free associating, clustering allows learners to begin without clear ideas. So, it can be concluded that clustering can explore many ideas from mind. It is a good way to develop idea before starting the writing activity. The learners can do it on their own or with friends or classmates to try to find inspiration or ideas.

Dalam buku Quantum Learning (DePotter dan Hernacki, 2000:182-184) ada beberapa prosedur atau langkah-langkah dalam penggunaan teknik clustering. Langkah-langkahnya adalah sebagai berikut :

1) Menuliskan gagasan utama berupa sebuah kata atau frasa yang terlintas dalam benak sebagai kata primer atau gagasan utama ditengah-tengah selembar kertas kosong tak bergaris dengan hurup capital dan tulisan yang lebih tebal dari pada tulisan yang lainnya.

2) Menuliskan hubungan-hubungan (asosiasi) yang timbul dari gagasan utama dan mengelompokan disekitar kata primer yang berada di pusat.

3) Melingkari setia kata yang telah dikelompokan disekitar gagasan utama dan menghubukannya dengan lingkaran yang berada dipusat dan tariklah garis.

4) Menuliskan penulisan hubungan-hubungan (asosiasi) dari kata-kata skunder yang memicu satu rantai atau asosiasi lain, menuliskan serta melingkarinya sekalipun tidak terlihat hubungannya.

5) Kembali pada kata primer (gagasan utama) yang terletak dipusat dan meneruskan membuat asosiasi yang terlintas dalam otak, kemudian melingkari dan menghubungkannya dengan menarik garis.

6) Memperhatikan semua gagasan yang dimunculkan dari satu kata setelah pengelompokan terasa lengkap dan semua asosiasi telah terkumpul.

7) Mencoret gagasan-gagasan yang dianggap tidak berhubungan atau tidak ingin dilanjutkan lagi dan kembali menuliskan gagasan-gagasan skunder yang memicu asosiasi-asosiasi lain. 
ALSUNIYAT: Jurnal Penelitian Bahasa, Sastra, dan Budaya Arab

8) Menemukan "AHA" (desakan untuk memulai menulis) dan memberi no urut yang tampaknya logis pada setiap kata atau gagasan dalam pengelompokan tersebut.

9) Mengembangkan gagasan berdasarkan urutan yang telah dibuat dalam pengelompokan kedalam bentuk karangan atau tulisan. Tidak perlu untuk memakai semua kata atau gagasan yang terdapat dalam pengelompokan, cukup gagasan yang ingin digunakan.

\section{METODE}

Pada penelitian ini, metode yang digunakan adalah metode quasi experimental. Jenis eksperimen ini hampir sama dengan true experimental, yakni terdapat dua kelompok yang diberikan pretest untuk mengetahui keadaan awal, hanya saja sampel tidak dipilih secara random. Kuasi eksperimen hampir mirip dengan eksperimen sebenarnya, perbedaannya terletak pada penggunaan subjek. Pada kuasi eksperimen sampel tidak dipilih secara random, melainkan dengan menggunakan kelompok yang telah ada.

Metode penelitian yang digunakan dalam penelitian ini adalah metode eksperimen kuasi dengan pendekatan kuantitatif. Peneliti menggunakan metode eksperimen kuasi karena penelitian ini menggunakan dua variabel. Menurut Sukmadinata (2012: 212) mengatakan bahwa "eksperimen kuasi merupakan penelitian untuk mengukur pengaruh suatu atau beberapa variabel terhadap variabel lain". Adapun design penelitian yang digunakan adalah nonekuivalent control group design. Dalam penelitian ini populasi yang digunakan yaitu kelas XI dengan sample yang digunakan yaitu kelas XI A dan XI C di MA Pesantren Modern Daarul Uluum Lido Bogor tahun ajaran 2014-2015. Kelas XI A sebagai kelas eksperimen karena sedangkan kelas XII C sebagai kelas kontrol.

Jika dalam bidang ilmu yang lain instrumen penelitian sudah ada , berbeda halnya dengan bidang pendidikan. Dalam bidang pendidikan seringkali belum ada instrumen yang digunakan untuk meneliti. Sehingga peneliti harus menyusun, membuat, dan mengembangkan instrument itu sendiri. Agar instrument tersebut dapat digunakan, terlebih dahulu instrument tersebut harus diuji. Oleh karena itu, maka peneliti berupaya menguji coba instrumen yang sudah dibuat. Agar mengetahui layak tidaknya instrument tersebut untuk digunakan sebagai instrument penelitian. Uji instrument tesebut meliputi uji validitas, reabilitas, tingkat tingkat kesukaran dan daya pembeda.

Setelah memperoleh semua data yang dibutuhkan, maka selanjutnya adalah mengolah dan menganalisis data. Adapun analisis data yang peneliti gunakan dalam penelitian ini adalah sebagai berikut: 
1. Observasi, yang bertujuan untuk memperoleh data tentang keadaan lingkungan sekolah serta proses belajar mengajar Bahasa Arab di ruang kelas dan dilingkungan sekolah dan apakah media audio visual film kartun berbahasa Arab telah digunakan dalam pembelajaran Insya ataukah belum sama sekali digunakan.

2. Angket atau kuesioner adalah sejumlah pertanyaan tertulis yang digunakan untuk memperoleh informasi dari responden dalam arti laporan tentang pribadinya, atau hal-hal yang ia ketahui. Angket atau kuesioner ini diberikan kepada siswa setelah selesai seluruh pelaksanaan tindakan. Penyebaran angket ini bertujuan untuk mengetahui respon siswa terhadap pembelajaran Insya dengan menggunakan media audiovisual terhadap penguasaan Insya

3. Tes

Tes diberikan sebanyak dua kali, yaitu pretest dan postest. Tes tersebut dilakukan sebelum dan sesudah perlakuan dengan menggunakan media audio visual film kartun berbahasa Arab terhadap kelas eksperimen dan tanpa perlakuan penggunaan media audio visual film kartun berbahasa Arab kepada kelas kontrol. Pretest digunakan untuk mengetahui kemampuan siswa kelas eksperimen dan kelas kontrol mengenai penguasaan Insya sebelum dilakukan pembelajaran dengan menggunakan Metode Clustering dan metode pembelajaran konvensional untuk kelas kontrol. Adapun pos test dilakukan untuk mengetahui kemapuan siswa tentang penguasaaan Insya setelah dilakukan pembelajaran dengan menggunakan teknik clustering pada kelas eksperimen dan metode konvensional pada kelas kontrol.

\section{HASIL DAN PEMBAHASAN}

Hasil penelitian diperoleh dari data-data yang telah dikumpulkan oleh peneliti selama melakukan penelitian yaitu nilai hasil pretest dan postest dari kelas eksperimen dan kelas kontrol. Sedangkan pembahasan merupakan paparan dari hasil-hasil data yang diperoleh slama penelitian berlangsung. Berikut ini adalah hasil dan pembahasan dalam penelitian ini:

Dalam penelitian ini hasil penelitian diperoleh dari pretest dan postest yang dilakukan di kelas eksperimen dan kelas kontrol. Pretest dilakukan sebelum menggunakan teknik clustering, sedangkan postest dilakukan setelah menggunakan teknik clustering. Adapun di bawah ini merupakan perhitungan pretest dan postest dari kelas kontrol dan eksperimen:

Pretest dilakukan pada kedua kelas yaitu kelas kontrol dan eksperimen untuk mengetahui kemampuan menulis awal siswa sebelum diberikan treatmen dengan 
menggunakan teknik clustering. Hasil pretest kelas kontrol dan eksperimen terlihat pada tabel di bawah ini:

1. Deskripsi hasil pretest kelas kontrol dan eksperimen

Berdasarkan hasil penelitian peneliti, dapat diketahui bawa nilai rata-rata pretest kelas kontrol sebesar 75,87 dengan nilai minimumnya sebesar 75,00 dan nilai maksimumnya sebesar 83,00. Serta standar deviasinya yaitu sebesar 30,47. Sedangkan nilai rata-rata pretest kelas eksperimen yaitu sebesar 79,07 dengan nilai minimumnya sebesar 75,00 dan nilai maksimumnya sebesar 83,00. Serta standar deviasinya yaitu sebesar 2,282.

Setelah melakukan pretest, selanjutnya peneliti melakukan treatment di kelas eksperimen dengan menggunakan teknik clustering. Sedangkan di kelas kontrol pembelajaran menulis tidak menggunakan teknik clustering. Setelah treatment diberikan, peneliti selanjutnya memberikan postest di kelas kontrol dan kelas eksperimen. Postest diberikan dengan tujua untuk mengetahui Hasil postest kelas kontrol dan kelas eksperimen terlihat pada tabel di bawah ini:

2. Deskripsi hasil postest kelas kontrol dan eksperimen

Berdasarkan hasil penelitian peneliti, dapat diketahui bawa nilai rata-rata pretest kelas kontrol sebesar 78,00 dengan nilai minimumnya sebesar 75,00 dan nilai maksimumnya sebesar 78,00. Serta standar deviasinya yaitu sebesar 0,990. Sedangkan nilai rata-rata pretest kelas eksperimen yaitu sebesar 82,27 dengan nilai minimumnya sebesar 78,00 dan nilai maksimumnya sebesar 85,00. Serta standar deviasinya yaitu sebesar 1,870.

Dalam pembahasan penelitian ini ada 4 kriterian penskoran, yaitu 1) Kerapihan dan kejelasan tulisan 2) Kesesuaian isi dengan judul yang diingikan 3) Penguasaan kosa-kata 4) Penguasaan gramatikan.

Berikut penjelasan hasil dari penskoran diatas sebelum dan sesudah menggunakan metode clustering:

\section{Kerapihan dan Kejelasan Tulisan}

Pada kriteria ini siswa mempunyai karakter masing-masing dalam kerapihan dan kejelasan tulisan, namun dalam kriteria yang sudah ditentukan oleh peneliti, sekitar 60\% siswa sesuai dengan kriteria yang sudah ditentukan dan 40\% nya tidak sesuai, hasil tersebut dilaksanakan sebelum tes dengan menggunakan teknik clustering.

Namun, setelah kriteria kerapihan dan kejelasan sudah ditentukan oleh peneliti dan tes menggunakan teknik clustering, seluruh siswa behasil menyesuaikan dengan kriteria. Hanya 
saja soal kerapihan penulisan siswa punya keterampilan masing-masing, tapi secara keseluruhan sesuai dengan tata cara oenulisan ke Araban.

\section{Kesesuaian Isi dengan Judul yang Diinginkan}

Ini merupakan tes inti dari penelitian ini, karena berdasarkan kesesuaian dengan judul yang diinginkan sangat berkaitan dengan tenik yang peneliti ajukan dalam penelitian ini.

Peneliti dalam kriteria ini sudah menentus soal tes dan sudah divalidasi secara judgment, dan berikut soal yang peneliti ajukan dan sudah divalidasi :

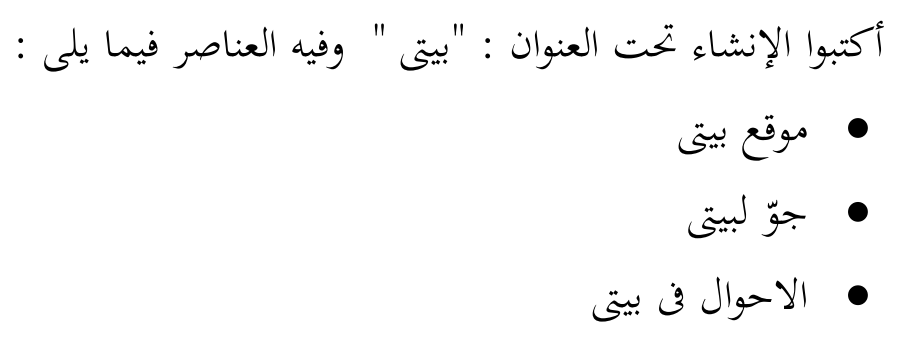

Sebelum menggunakan teknik clustering, siswa masih merasa kebingungan bagaimana cara mengatur kata-kata dalam membuat insya. Karena masih sulit harus memulai dari mana dan apa saja yang harus dibuat dalam mebuat insya. Maka dari itu, sebanyak $70 \%$ siswa tidak sesuai dengan kriteria yang sudah ditentukan oleh peneliti.

Setelah siswa diberikan penjelasan tentang menulis insya menggunakan teknik clustering, siswa merasa terbuka pikirannya karena sudah diberikan pencerahan dengan menggunakan teknik clustering. Setelah dilakukan tes dan dinilai, hasil secara keseluruhannya yaitu sebayak 82,7\% hasil dari tes berdasarkan kesesuaian dengan judul yang diinginkan sesuai dengan kriteria tes yang diberikan, dan 18,3\% nya masoih berupaya menggali potensi mereka dalam pembelajaran insya ini.

\section{Penguasaan Kosa Kata}

Karena lingkungan yang siswa tempati merupakan lingkungan pesantren yang fokus terhadap kebahasaan, maka siswa sudah menguasai penuh tentang kosa kata yang berkaitan dengan judul insya yang diberikan peneliti. Peraturan yang ada di sekolah tersebut mewajibakan kepada seluruh siswa untuk menggunakan bahasa Ara dan bahasa Inggris setiap harinya, bahkan ada hukuman jika siswa tidak menggunakan dua bahasa tersebut.

Tidak ada perbedaan yang yang menonjol dalam kriteria ini sebelum dan sesudah menggunakan teknik clustering, karena kemampuan siswa tentang penguasaan kosa-kata merata secara keseluruhan.

\section{Penguasaan Gramatika}


Penguasaan gramatika tidak luput dari penyajian bahan pelajaran dengan jalan menghafal dan mengetahui aturan-aturan atau kaidah kaidah tata bahasa Arab yang mencakup nahwu dan shorof. Insya (menulis) merupakan keterampilan terakhir dari empat keterampilan bahasa. Maka dari itu, insya harus mencakup tiga keterampilan sebelumnya yaitu membaca, mendengar, dan berbicara. Dan pastinya harus sesuai dengan gramatika bahasa yang ditulis dalam hal ini adalah bahasa Arab. Sudah dijelaskan pada kriteria sebelumnya bahwasannya lingkungan pesantren yang diteliti penulis merupakan lingkungan berbahasa asing yaitu bahasa Arab dan bahasa Inggris. Maka, otomatis didalam pembelajarannya diajarkan gramatika baik bahasa Arab ataupun Inggris.

Maka, Tidak ada perbedaan yang yang menonjol dalam kriteria ini sebelum dan sesudah menggunakan teknik clustering, karena kemampuan siswa tentang penguasaan kosa-kata merata secara keseluruhan.

\section{KESIMPULAN}

Berdasarkan hasil perhitungan dan analisis data penelitian yang diperoleh, maka pada bagian ini penulis dapat menarik kesimpulan sebagai berikut:

a. Nilai rata-rata pretes kemampuan menulis insya pada pretes di kelas eksperimen sebesar 79,07 dan postes sebesar 82,27. Peningkatan nilai rata-rata siswa sebesar 3,2. Adapun nilai rata-rata pretes kemampuan menulis insya di kelas kontrol sebesar 75,87 dan postes sebesar $\vee \wedge$. Peningkatan nilai rata-rata di kelas kontrol sebesar 2,13 Peingkatan nilai ratarata kemampuan menulis insya di kelas eksperimen lebih besar dibandingkan peningkatan nilai rata-rata di kelas kontrol.

b. Berdasarkan peningkatan kemampuan yang telah dicapai oleh kelas eksperimen dan kelas kontrol maka terlihat bahwa terdapat perbedaan peningkatan antara kelas eksperimen dengan kelas kontrol, dan dapat dikatakan bahwa penggunaan media audiovisual film kartun berbahasa Arab efektif dalam peningkatan insya dibandingkan dengan metode konvensional dengan tanpa penggunaan media audiovisual film kartun berbahasa arab. Efektifitas penggunaan media audiovisual film kartun berbahasa Arab terhadap penguasaan insya dapat dilihat dari hasil peningkatan (gain) dari kedua kelas tersebut.

c. Berdasarkan hasil penghitungan statistik, nilai signifikansi (2-tailed) dibagi dua sebesar 0,000. Karena $0,000<\alpha=0,05$, maka $\mathrm{H}_{0}$ ditolak dan Ha diterima. Hal ini menunjukkan adanya perbedaan yang signifikan antara kemampuan menulis insya dengan menggunakan media audiovisual film kartun berbahasa Arab. Media audiovisual film kartun berbahasa Arab efektif digunakan dalam pembelajaran insya. 


\section{DAFTAR PUSTAKA}

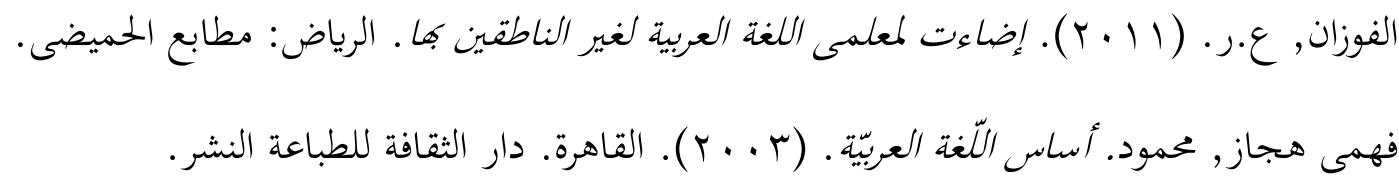

Al Khauly, Muhammad Ali. (2002). Model Pembelajaran Bahasa Arab. Bandung. Pusat Studi Islam dan Bahasa Arab (PSIBA).

Alfiyah, N. (2012). Pentingnya Menulis Bagi Mahasiswa. [Online]. Diakses dari: http://m.kompasiana.com/post/read/497698/3/pentingnya-menulis-bagimahasiswa.html. [20 Januari 2015].

Cahyani. (2002). Kemampuan Berbahasa Indonesia di Sekolah Dasar. Bandug : UPI Press.

Dawson and Essid in http: www.writing2.richmond.edu/writing/wweb/cluster. html-4k accessed on [December 7th 2009].

De Potter, B \& Hernacki M .(2000). Quantum Learning. Bandung: Pustaka Setia.

Hernowo. (2006). Quantum Writing Cara Cepat nan Bermanfaat untuk Merangsang Munculnya Potensi Menulis. Bandung: MLC.

Keraf, Gorys. (1982). Komposisi. Jakarta: Ikrar Mandiri Abadi.

Nurgiyantoro , Burhan. (1995). Penilaian dalam Pengajaran Bahasa dan Sastra. Yogyakarta: BPFE.

Nurgiyantoro, Burhan. (2001). Penilaian dalam Pengajaran Bahasa dan Sastra. Yogyakarta: BPFE

Rahardi, R.K. (2009). Surat-Menyurat Dinas. Yogyakarta: Pustaka Book Publisher.

Tarigan, Henry Guntur. (1994). Menulis Sebagai suatu keterampilan berbahasa. Bandung: Angkasa.

Tarigan, Henry Guntur. (2008). Menulis Sebagai suatu keterampilan berbahasa. Bandung: Angkasa. 